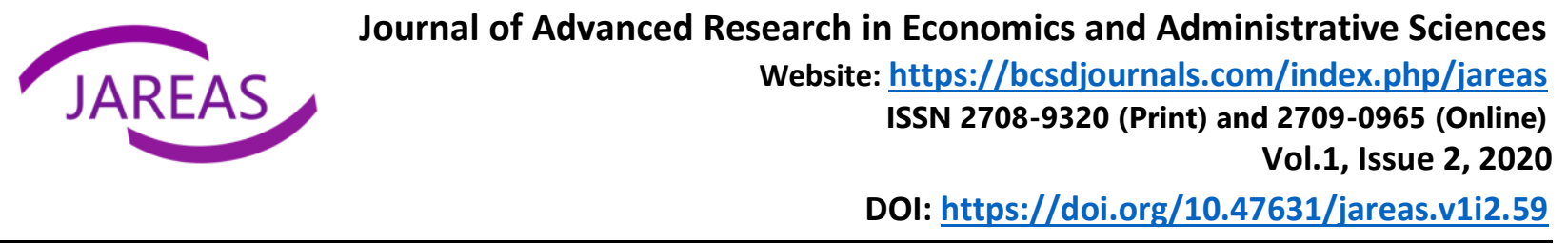

\title{
Effect of Interest Rate Liberalisation on Domestic Savings in Nigeria
}

\section{Olusola Dahunsi ${ }^{1}$}

\author{
${ }^{1}$ Department of Economics, Obafemi Awolowo University, Ile-Ife, Nigeria
}

\author{
Article Info \\ Article history: \\ Received:23 September 2020 \\ Revised: 02 November 2020 \\ Accepted: 04 November 2020 \\ Keywords: \\ Interest Rate Liberalization, \\ Domestic Savings, \\ Capital Formation. \\ JEL: G17, G51, H83, G30. \\ Paper Type : \\ Research Article \\ Corresponding Author: \\ Olusola Dahunsi \\ Email: \\ olusoladahunsi@yahoo.com
}

\begin{abstract}
Purpose: Empirical investigations into the interest rate effects on domestic savings have provided mixed results. Hence, this study examined the interest rate effects on domestic savings in line with the financial liberalization hypothesis since the period of structural adjustment program (SAP) in Nigeria.

Approach/Methodology/Design: Data on gross domestic savings, interest rate, gross capital formation, and rate of inflation from 1986 to 2018 were obtained and analyzed using the autoregressive distributed lag (ARDL) technique.

Findings: The results revealed that interest rate and gross domestic savings are co-integrated in the long-run. The study showed that while capital formation positively affects domestic savings, the interest rate affects domestic savings negatively since the economic reforms of 1986 in Nigeria.

Practical Implications: The results of the study are important for the Nigerian government to promote home-grown investments through domestic savings and capital formation. This will be made possible in the face of interest rate liberalization in which a higher interest rate serves as incentives for the household to save more thereby increasing domestic savings of the economy.

Originality/value: The study further revealed that the long-run relationship exists between domestic private investments and interest rates.
\end{abstract}

\section{Introduction}

Domestic savings are crucial for the mobilization of financial capital for investment opportunities. Unlike investment borrowings and loans from abroad which expose the economy to foreign exchange risk and are serviced in the future, domestic savings and investment have been viewed as preconditions for capital formation that ultimately improve economic growth (Adelakun, 2015). However, domestic saving is influenced by several interdependent variables ranging from the level of income and household consumption (Reinhart \& Ostry, 1995) to the interest rate elasticity of savings (Corsepius \& Fischer, 1986).

The interest rate, described as the rate of returns on investment, is one of the important economic variables in any economy. Much more than a monetary instrument employed by monetary authorities, the interest rate is a vital economic variable that informs the decisions of a wide range of individuals, firms, investors, and government because it influences the mobilization of financial capital through domestic savings for investment opportunities. Nevertheless, developing countries like Nigeria are characterized by inadequate monetary policies in channeling savings towards investment opportunities (Adom \& Elbahnasawy, 2014).

In Nigeria, interest rate operation has witnessed policy changes overtime from the period of the fixed regime to the period of the flexible regime of the interest rate. The regulated regime before 
the structural adjustment program (SAP) was characterized by a low-interest rate to stimulate domestic savings and investment but this direct control of the economy worsened the macroeconomic instability. The introduction of SAP in 1986 which was accompanied by the liberalization of interest rate in 1987 allowed the operations of interest rate to be controlled by the market forces to ensure the efficient allocation of resources (Ene et al. 2015). Despite the policy framework of SAP to liberalize the economy, enhance foreign exchange and create employment, the interest rate continued to be volatile, the value of the currency depreciated unceasingly, and unemployment deteriorated. Thus, the uncertainty that surrounds the liberalization of interest rate affects domestic savings which are crucial for investment and industrial outputs that enhance economic growth (see figure 1).

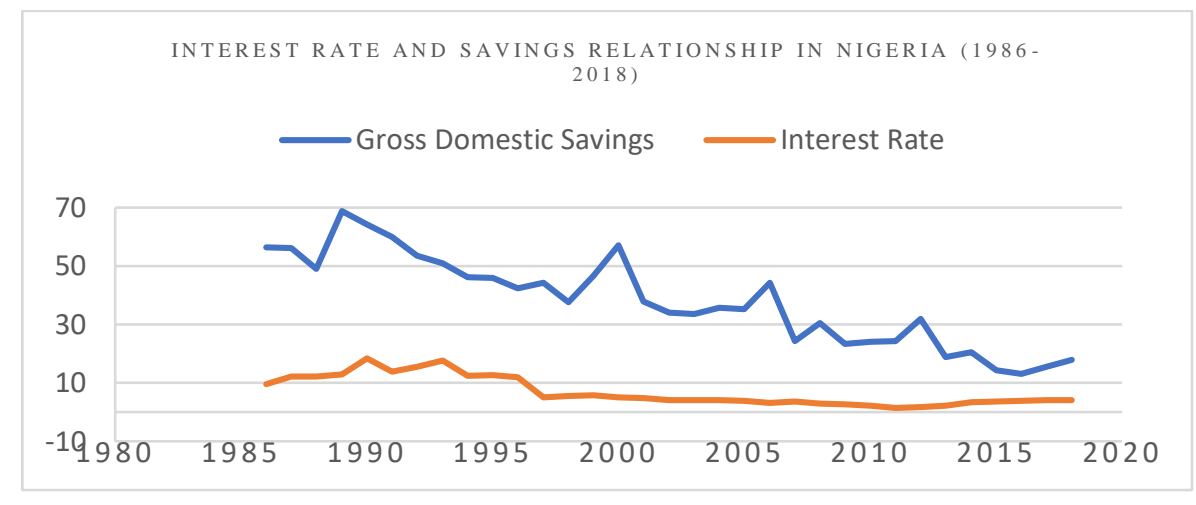

Figure 1: Interest Rate-Domestic Savings Relationship in Nigeria (1986-2018) Source: Author's Computation, 2020.

Domestic savings play a crucial role in sustaining an investment-growth relationship in developing economies (Lewis, 1970). Unlike foreign capital flows (such as foreign private investment) that expose the host economy to external shocks, domestic savings is capable of providing a stable source of capital to bridge the financial gap in investment, $R \& D$, and innovation (Grocer et al., 2016). For most of the developed economies, the volume of domestic savings-investment is usually outweighing foreign capital flows (Moses et al., 2013). However, many developing economies are characterized by high dependence on foreign capital flows and low domestic savings. Hence, they are vulnerable to external shocks and high debt profile which results in macroeconomic instability (Gocer et al., 2016).

Furthermore, interest rate liberalization has become an important economic policy among developing economies to improve domestic savings in achieving an efficient allocation of resources for investment opportunities which will be difficult to achieve in the face of interest rate repression in the economy (Mackinnon, 1973; Shaw, 1973; Corsepius \& Fischer, 1986). However, scholars disagree on the interest rate effect on domestic savings. The loanable fund theory of the classical school postulated that a higher rate of interest incentivizes households to save, thus, there exists a positive relationship between the interest rate and domestic savings. Conversely, Keynes (1936) in his liquidity preference theory posited that higher interest rate discourages savings. He argued that an expected rise in the price of investment (bonds) results in high speculative demand for money to buy bonds thus interest rates will fall (Keynes, 1936). 
Equally, an expected decrease in the price of the bonds will reduce speculative demand for money as investors sell their bonds, and then the rate of interest will rise.

Controversies abound in the literature on the interest rate effect on domestic savings. Studies by Giovannini (1983); Onwumere, Okore and Ito (2012); Simon-Oke and Jolaosho (2013); Udede (2015) revealed that interest rate negatively affects domestic savings. In contrast, Fry (1978); Opuku and Ackah (2015) and Aizenman, Ito and Cheung (2016) showed positive effects of interest rate on domestic savings. Other studies by Thirlwall, (1979), Adelakun (2015), Wuhan and Khirshid (2015), and Inimino, Abuo and Bosco (2018) revealed that a long-run relationship exists among the rate of interest, savings-investment, and capital formation. Given the disagreements among scholars on the interest rate effect on domestic savings-investment and the disincentive that interest rate repression could have on domestic savings Mackinnon (1973) and Shaw (1973), there is a need to examine the effect of interest rate on domestic savings in Nigeria since the liberalization of interest and structural adjustment program of 1986.

\section{Literature Review}

The study by Onwumere, Okore and Ibe (2012) examined the effects of liberalization of interest rate on savings in Nigeria between 1976 and 1999. The linear regression model was adopted and the study revealed that the liberalization of interest rate has a significant negative effect on savings and investment. Thus, interest rate liberalization produced a counterproductive effect on savings and investment, although the liberalization of interest rate policy is designed to improve savings and investment. In a related vein, Simon-Oke and Jolaosho (2013) studied the nexus between the interest rate and mobilization of savings between 1980 and 2008 in Nigeria. Vector autoregressive model was employed and the study revealed that the interest rate harms savings in the economy. The study concluded that the liberalization of interest rate discourages savings mobilization which in turn affects the capital formation and investment in the economy.

Moreover, Udude (2015) investigated the interest rate impact on savings on the Nigeria economy between 1981 and 2013. Using the vector- autoregression approach, the results showed that interest rate negatively affects savings for the period under study. However, the study further showed that GDP has a significant positive effect on domestic savings. The study concluded that the combined effect of interest rate and GDP significantly affects the propensity to save. Furthermore, Aizenman, Ito and Cheung (2016) examined the interest rate effect on private savings among 135 Asian countries between 1995 and 2014. Using baseline estimation to investigate the interest rate and private savings nexus, the study showed that the interest rate exerts a significant positive effect (substitution effect) on private savings for all Asian countries used in the study. However, the negative effect (income effect) of the real interest rate was established among emerging market economies when the nominal interest rate goes below $2.5 \%$.

Wuhan and Khirshid (2015) studied the interest rate-investment relationship in China between 2003 and 2012. Using the VECM technique, the study showed that the interest rate has a significant negative impact on investment in the long-run, although, the interest rate also exhibited a positive effect on investment in the short-run. The study further showed that the 
long-run relationship exists between the interest rate and investment in China. Similarly, George-Anokwuru (2017) assessed the relationship between domestic private investment and interest rates between 1980 and 2015 in Nigeria. Adopting the OLS regression technique, the study showed that the prime lending rate and the interest rate exhibited a significant negative effect on domestic private investment at a 5\% level. The study concluded that domestic private investment depends on other macroeconomic factors apart from the interest rate.

Inimino et al. (2018) examined the effect of interest rate (proxied by prime lending rate, monetary policy rate and maximum lending rate) on domestic investment in Nigeria between 1980 and 2015. The study used an autoregressive distributed lag technique and showed that both prime lending and monetary policy rates have significant negative effects on domestic private investments while the maximum lending rate exerts a long-run positive effect on domestic investment at a 5\% level of significance. The study further revealed that the long-run relationship exists between domestic private investments and interest rates.

Financial liberalization has been considered as a crucial economic reform in all countries of the world (Corsepius \& Fischer, 1986). Specifically, it has been viewed as a crucial factor for developing economies in attaining economic growth and development (Belassa, 1989). According to McKinnon (1973) and Shaw (1973), financial liberalization involves the establishment of a high-interest rate that promotes domestic savings for investment purposes. Thus, a higher interest rate encourages domestic savings which consequently enhances the efficiency of investment that is based on the market-driven interest rate. Conversely, financial repression (or the absence of financial liberalization) keeps the rate of return below the equilibrium level and reduces the amount of savings in the economy. Shaw (1973) opined that when the rate of interest is suppressed below the equilibrium level, investors will resort to selffinancing of investment and as such savers' investment are channeled towards consumptions of goods that are not directly related to production leading to capital tied down and over-investment which create excess capacity (McKinnon, 1973).

\section{Methodology and Procedures}

McKinnon (1973) and Shaw (1973) developed the financial liberalization which postulates that interest rate enhances domestic savings by equating demand for money to supply of money. Thus, the interest rate effect on domestic savings in Nigeria is examined since the structural adjustment program of 1986. Thus, domestic savings is specified thus:

$$
\text { Savings }=f(\text { Interest })
$$

Following the studies of Athukorala (1998), Udude (2015) and Adelakun (2015) on interest rate and savings, rate of interest (INT), gross capital formation (GCF), inflation rate (INF) are included as explanatory variables in the savings function.

$$
\begin{gathered}
D S A=f(I N T, G C F, I N F) \\
D S A_{t}=\alpha_{0}+\alpha_{1} I N T_{t}+\alpha_{2} G C F_{t}+\alpha_{3} I N F_{t}+\varepsilon_{t}
\end{gathered}
$$

Where DSA represents gross domestic savings as a percentage of the gross domestic product, INT represents the rate of interest on savings, GCF is gross capital formation. Also, INF 
represents the rate of inflation. The log form of the model is expressed in equation (4) except for some of the variables that are already in rates or net values;

$$
L D S A_{t}=\alpha_{0}+\beta I N T_{t}+\delta L G C F_{t}+\sigma I N F_{t}+\varepsilon_{t}
$$

Note that $\varepsilon_{t}$ is a residual term assumed to be white noise. In examining the interest rate effect on domestic savings, we employ the autoregressive distributed lag developed by Pesaran, Shin and Smith (2001). The fundamental importance of this model is that we can simultaneously discuss the long-run and short-run effects within the same framework especially when the variables are not of the same order of integration, that is; when the study comprises stationary and nonstationary variables. The ARDL model of equation (4) is formulated as follows:

$$
\Delta D S A_{t}=\alpha_{0}+\sum_{i=1}^{p} \delta_{i} D S A_{t-i}+\sum_{i=0}^{q} \phi_{i} \Delta I N T_{t-i}+\sum_{i=0}^{q} \theta_{i} \Delta G C F_{t-i}+\alpha_{1} D S A_{t-1}+\alpha_{2} I N T_{t-1}+\alpha_{3} G D I_{t-1}+\varepsilon_{t}
$$

The existence of long-run relationships is established by performing the joint significance of long-run coefficients of the variables in equations (5).

The study made use of secondary data. Annual data from 1986 to 2018 on gross capital formation, inflation rate, and gross domestic savings were sourced from World Bank Indicator (WDI) Index, 2019 edition, while data on interest rate was sourced from the Statistical Bulletin of the Central Bank of Nigeria, 2020 edition.

\section{Results and Discussion}

The descriptive statistics (mean and median values) are highly consistent as they are perpetually within the maximum and minimum values in the data set as presented in Table 1. The skewness of all variables is positive. The values of the Jarque-Bera statistic showed normal distribution of all variables given that the probability values of all the series are insignificant at 5\% level except inflation rate series. Thus, the null hypothesis of the normal distribution of variables is accepted.

Table 1: Summary of Descriptive Statistics

\begin{tabular}{lllll}
\hline & DSA & INT & GCF & \multicolumn{1}{l}{ INF } \\
\hline Mean & 38.11937 & 6.963333 & 31.40646 & 19.94959 \\
Median & 37.62452 & 4.190000 & 29.38680 & 12.55496 \\
Maximum & 68.80762 & 18.39000 & 54.95059 & 72.83550 \\
Minimum & 13.08044 & 1.410000 & 14.90391 & 5.388008 \\
Std. Dev. & 15.49270 & 5.020373 & 13.05102 & 18.27968 \\
Skewness & 0.092902 & 0.876673 & 0.239909 & 1.610963 \\
Kurtosis & 2.005720 & 2.372801 & 1.754532 & 4.216073 \\
Jarque-Bera & 1.406783 & 4.767955 & 2.449445 & 16.30700 \\
Probability & 0.494904 & 0.092183 & 0.293839 & 0.000288 \\
Sum & 1257.939 & 229.7900 & 1036.413 & 658.3364 \\
Sum Sq. Dev. & 7680.765 & 806.5325 & 5450.531 & 10692.7 \\
Observations & 33 & 33 & 33 & 33 \\
\hline
\end{tabular}

Note: DSA, INT, GCF, and INF represent domestic savings, rate of interest, 
gross capital formation, and inflation rate.

Source: Author's Computation, 2020.

\section{Results of the Stationarity Test}

The Augmented Dickey-Fuller and Philip Perron unit root tests showed that inflation rate (INF) is stationary at the level I (0) while domestic savings (DSA), gross capital formation $(G C F)$, and interest rate (INT) are stationary at the first difference I (1) as shown in Table 2.

Table 2: Stationarity Test Results

\begin{tabular}{|c|c|c|c|c|c|c|}
\hline & ADF Test & & & PP Test & & \\
\hline Variables & Level & First Diff & Status & Level & First Diff & Status \\
\hline \multirow[t]{2}{*}{ DSA } & -0.8776 & -5.8434 & $\mathrm{I}(1)$ & -1.0543 & -22.4960 & $\mathrm{I}(1)$ \\
\hline & [0.7818] & {$[0.0000] * * *$} & & {$[0.7213]$} & {$[0.0001]^{* * *}$} & \\
\hline \multirow[t]{2}{*}{ INT } & -2.1691 & -3.2545 & $\mathrm{I}(1)$ & -1.1685 & -7.0684 & $\mathrm{I}(1)$ \\
\hline & [0.2211] & {$[0.0272]^{* *}$} & & {$[0.6756]$} & {$[0.0000]^{* * *}$} & \\
\hline \multirow[t]{2}{*}{ GCF } & -1.6454 & -5.4986 & $\mathrm{I}(1)$ & -1.8150 & -5.8347 & $\mathrm{I}(1)$ \\
\hline & [0.4484] & {$[0.0001] * * *$} & & [0.3668] & {$[0.0000] * * *$} & \\
\hline \multirow[t]{2}{*}{ INF } & -4.2501 & ------------ & $\mathrm{I}(0)$ & -2.7776 & --------- & $\mathrm{I}(0)$ \\
\hline & {$[0.0029] * * *$} & ------------ & & {$[0.0728]^{*}$} & --------- & \\
\hline
\end{tabular}

Note: DSA, INT, GCF, and INF represent domestic savings, interest rate, capital formation, and rate of inflation respectively.

Source: Author's Computation, 2020.

\section{Interest Rate and Domestic Savings: Long-run Relationship}

The bound test of ARDL is reported in Table 3. It is observed that the F-statistic (7.2140) is higher compared to the upper bound value (4.35) of the table at a 5\% significant level which necessitates the rejection of the null hypothesis. Hence, the alternative hypothesis is accepted which stipulates that at a 5\% significant level, a long-run relationship exists among interest rates, domestic savings, gross capital formation, and inflation rate in Nigeria between 1986 and 2018.

Table 3: Bound Test Result

\begin{tabular}{lll}
\hline Variables & F-Statistics & Cointegration \\
\hline$F(D S A / I N T, G C F, I N F)$ & 7.2140 & Cointegration \\
Critical Value & Lower Bound & Upper Bound \\
$1 \%$ & 4.29 & 5.61 \\
$5 \%$ & 3.23 & 4.35 \\
$10 \%$ & 2.72 & 3.77 \\
\hline
\end{tabular}

Source: Author's Computation, 2020. 


\section{Interest Rate Effects on Domestic Savings}

The long-run result in Table 4 shows that the rate of interest has a negative effect on domestic savings. At a 5\% level of significance, the coefficient of interest rate $(-2.7241)$ revealed that an increase in the rate of interest leads to a 2.72 unit decrease in domestic savings in the long-run. This result refutes the $a$ priori expectation of interest rate effect on domestic savings as postulated by McKinnon (1973) and Shaw (1973) who stated that the liberalization of interest rate enhances domestic savings and promotes economic growth. Rather, the result showed that at a 5\% level interest rate exerts a significant negative effect of domestic savings since the financial reforms of 1986 in Nigeria. Generally, interest rate operation is being suppressed by some other policies which hindered the operation of the invisible hand of demand and supply. Specifically, it was observed that a cap was placed on interest rate operations in 1994 and since then interest rate has dwindled in Nigeria. The result of this study is consistent with Onwumere et al. (2012); Simon-Oke and Jolaosho (2013) and Udede (2015) among others which revealed a negative effect of interest rate operations on savings in Nigeria.

Furthermore, capital formation positively affects domestic savings. The gross capital formation coefficient (1.8418) is significant at a 5\% level and implies that an increase in capital formation leads to a 1.84-unit rise in domestic savings as shown in Table 4. This result supports the assertion of Thirlwall (1979) who opined that capital formation promotes economic growth. Adelakun (2015) also corroborated that capital formation enhances greater productivity of workers and subsequently increase per capita income. Similarly, the rate of inflation positively affects domestic savings in Nigeria. The coefficient of inflation rate $(-0.4312)$ shows that an increase in the inflation rate increases domestic savings by 0.43 units.

The short-run relationship in Table 4 showed the effects of interest rate, gross capital formation, and inflation on domestic savings. The result showed that the coefficient of interest rate in lag one period (INT(-1)) is 2.0057 which implies that an increase in interest rate leads to 2.00 units increase in domestic savings at a 5\% significant level. Thus, a positive relationship exists between the previous year's interest rate and the current year's domestic savings. Also, the coefficient of lag three value (GCF (-3)) is 0.9375 and it shows a positive effect of gross capital formation on the domestic savings though not significant at a $5 \%$ level. However, lag two value of inflation rate (INF(-2)) with a coefficient of 0.3270 has a deleterious effect on domestic savings though not significant at $5 \%$ level.

The coefficient (1.1960) of error correction term (ECT) is negative at a 5\% level. The negative coefficient value of the ECT indicates that the speed of adjustment from the previous year's disequilibrium will revert and get corrected over time. This shows a stable process of adjustment to the long-run relationship. This means that each period, $119.60 \%$ of the previous period's error will be corrected. Also, the normality test as shown in Table 5 concludes that the model of equation (3.4) is normal. There is no evidence of serial correlation, hence, the model is homoscedastic and thus it is desirable. 
Table 4: The ARDL Results

\begin{tabular}{lllll}
\hline Dependent Variable: DSA & & \multicolumn{3}{c}{ SIC: ARDL $(1,3,4,2)$} \\
\hline & Coefficient & Std Error & t-Statistic & P-Value \\
\cline { 2 - 5 } Long-run Estimate & & & & \\
INT & -2.7241 & 0.9737 & -2.7976 & $0.0135^{* *}$ \\
GCF & 1.8418 & 0.2542 & 7.2447 & $0.0000^{* * *}$ \\
INF & 0.4312 & 0.2071 & 2.0821 & $0.0549^{*}$ \\
C & -7.7919 & 3.9664 & -1.9644 & $0.0683^{*}$ \\
Short-run Estimate & & & & \\
$\Delta_{\text {INT }}$ & 0.4587 & 0.7313 & 0.6271 & 0.5400 \\
$\Delta_{\text {INT }(-1)}$ & 2.0057 & 0.9433 & 2.1263 & $0.0505^{* *}$ \\
$\Delta_{\text {INT }(-2)}$ & 1.0527 & 0.6377 & 1.6507 & 0.1196 \\
$\Delta_{\text {GCF }}$ & 0.8160 & 0.5289 & 1.5427 & 0.1437 \\
$\Delta_{\text {GCF }}(-1)$ & -0.6543 & 0.5239 & -1.2489 & 0.2308 \\
$\Delta_{\text {GCF }(-2)}$ & -1.0046 & 0.5813 & -1.7281 & 0.1045 \\
$\Delta_{\text {GCF }(-3)}$ & 0.9375 & 0.4423 & 2.1194 & $0.0511^{*}$ \\
$\Delta_{\text {INF }(-1)}$ & 0.2122 & 0.1739 & 1.2202 & 0.2412 \\
$\Delta_{\text {INF }(-2)}$ & -0.3270 & 0.1654 & -1.9766 & $0.0668^{*}$ \\
ECT (-1) & -1.1960 & 0.2216 & -5.3951 & $0.0001^{* * *}$ \\
$R^{2}$ & 0.9379 & & & \\
F-Stat & 17.4488 & & & \\
\hline
\end{tabular}

Source: Author's Computation, 2020.

Table 5: ARDL Diagnostic Test Result

\begin{tabular}{|c|c|c|}
\hline Diagnostic Test Statistic & & \\
\hline Test & Value & P-value \\
\hline$\chi^{2}$ Normal & 0.7230 & 0.6966 \\
\hline$\chi^{2}$ Serial LM Test & 2.3087 & 0.1229 \\
\hline$\chi^{2}$ Hetero Test & 1.3790 & 0.2733 \\
\hline
\end{tabular}

\section{Conclusion and Suggestion}

The study confirmed that the rate of interest, domestic savings, gross capital formation, and inflation rate are cointegrated in the long-run. The study also showed that interest rate exerted a significant negative effect on domestic savings while gross capital formation had a positive effect on domestic savings at a 5\% significant level in the long-run. Theoretically, the liberalization of interest rate with the introduction of SAP was to provide abundant capital for investment opportunities, especially investment in the manufacturing sector which is considered as a principal-agent of industrialization. But, in 1994 the Nigerian government introduced certain measures to suppress interest rate operations during the flexible regime of interest rate $(\mathrm{CBN}$, 2010). However, McKinnon (1973) and Shaw (1973) argued that financial repression (indiscriminate distortion of financial and economic prices) retards economic growth. This study 
confirmed the deleterious effect of interest rate repression on domestic savings between 1986 and 2018 in Nigeria.

\section{Policy Recommendations}

The Nigerian government should promote homegrown investments through domestic savings and capital formation. This will be made possible in the face of interest rate liberalization in which a higher interest rate serves as incentives for the household to save more thereby increasing domestic savings of the economy. Given that higher savings result from a higher rate of interest, the level of domestic savings will consequently improve domestic investments and economic growth. Furthermore, the operations of interest rate policies should no longer be micro-managed or suppressed by the government, rather, policymakers should ensure that interest rate is expressly determined by the interplay of demand and supply in Nigeria.

\section{Conflict of interests}

The author declares no conflict of interest.

\section{Funding}

The study has no financial assistance/funds to recognize.

\section{References}

Adelakun, O. J. (2015). An investigation of the determinants of savings and investment in Nigeria. International Economies and Business, 1(2), 1-16. Doi: 10.5296/ieb.vli2.8688

Adom, A. D., \& Elbahnasawy, N. G. (2014). Saving-investment gap and economic growth in developing countries: Simulated evidence from selected countries in Africa. British Journal of Economics, Management and Trade 4(10), 1585 - 1598.

Aizenman, J., Cheung, Y., \& Ito, H. (2016). The interest rate effect on private saving: Alternative Perspectives. NBER Working Paper No. 22872

Anyanwu, K. N. (2011). The impact of foreign direct investment on Nigeria's economic growth.(Unpublished Thesis). Anambra, Nigeria: Nnamdi Azikiwe University.

Athukorala, P. C. (1998). Interest rates, saving and investment: Evidence from India, OxfordDevelopment Studies, 26(2), 153-169. Doi:10.1080/13600819808424151

Belassa, B. (1989). Financial liberalisation in developing countries. World Development Report Working Paper No. 55

Central Bank of Nigeria (2010). Statistical Bulletin and National Bureau of Statistics Publication of the year 2010 .

Central Bank of Nigeria (2020). Statistical Bulletin and National Bureau of Statistics Publication of the year 2020.

Corsepius, U. \& Fischer, B. (1986). Interest rate policies and domestic savings mobilisation. A survey of the empirical evidence of Asian countries, Kiel Working Paper No. 267, Institut for Weltwirtschagt (IfW), Kiel. http//hdl.handle.net/10419/46898 
Fry, M. J. (1978). Money and capital or financial deepening in economic development. Journal of Money Credit and Banking, 10(4), 464-475.

George-Anokwuru, C. C. (2017). Interest rate and domestic private investment in Nigeria. IIARD International Journal of Economics and Business Management 3(5), 43-49.

Giovannini, A. (1983). The interest elasticity of savings in developing countries. The existing evidence. World Development Report, 11(7), 601-607.

Grocer, I., Akin, T., \& Alatas, S. (2016). The effect of saving-investment in economic growth in developing countries: A clustering and panel data analysis. Theoretical and Applied Economics. 23(2), $157-172$.

Inimino, E. E., Abuo, M. A., \& Bosco, I. E. (2018). Interest rate and domestic private investment in Nigeria. International Journal of Research and Innovation in Social Science, 2(10), 198-206.

Jelilov, G. (2016). The impact of interest rate on economic growth example of Nigeria. African Journal of Social Sciences, 6(2), 51-64.

Keynes, J. M. (1936). The General Theory of Employment, Interest and Money.London: Macmillian.

Lewis, A. (1970). The Theory of Economic Growth. New York: Harper and Row.

McKinnon, R. I. (1973). Money and Capital in Economic Development, Brookings Institution, Washington, D.C., 1973.

Moses, C. O., Anigbogu T. U., Okoli M. I., \& Anyanwu K. N. (2013). Domestic investment and foreign direct investment flow in Nigeria; IOSR Journal of Humanities and Social Sciences, 13(6), $1-12$.

Onwumere, J. U. J., Okore O. A., \& Ibe, I. G. (2012). The impact of interest rate liberalization on savings andinvestment: Evidence from Nigeria. Research Journal of Finance and Accountingwww.iiste.orgISSN 2222-1697 (Paper) ISSN 2222-2847 (Online)3(10).

Opuku, R. T., \& Ackah, I. (2015). How responsive are private savings to changes in real interest rate in Ghana. Munich Personal RePEc Archive Paper No. 65040.

Pesaran, M. H., Shin, Y. C., \& Smith, R., (2001). Bound Testing Approaches to the Analysis of Level Relationships. Journal of Applied Econometrics, 16, 289-326.

Reinhert, C., \& Ostry, J. (1995). Savings and real interest rates in developing countries. Maryland:University of Maryland.

Shaw, E. S. (1973). Financial Deepening in Economic Development, Oxford University Press, 1973.

Simon-Oke, O. O., \& Jolaosho, M. (2013). Real interest rate and savings mobilization in Nigeria. International Journal of Development and Economic Sustainability1(2), 2840.

Thirlwall, A. P. (1979). Growth and Development: With Special Reference to Developing Economies (6th ed.)

Udude C. C. (2015). Impact of interest rate on savings on the Nigeria's economy. Journal of Policy and Development Studies, 9(3).

World Bank (2019). World Development Indicators Washington, D. C., USA. 
Wuhan, L. S., \& Kshirshud, A. (2015). The effect of interest rate on investment: Empirical evidence of Jiangsu province, China. Journal of International Studies 8(1), 81-90. Doi: 10.14254/2071-8330.2015/8-1/7.

Ene, E. E., Agok, S. A., \& Ene, J. C. (2015). Effect of Interest Rates Deregulation on the Performance of Deposit Money Banks in Nigeria. International Journal of Managerial Studies and Research, 3 (9), 164, 176. 